\title{
RB-SR AND U-PB AGE DETERMINATIONS ON SOUTHERN AFRICAN KIMBERLITE PIPES
}

H.L. Allsopp and J.D. Kramers (Bernard Price Institute of Geophysical

Research, University of the Witwatersrand, Johannesburg, 2001, South Africa)

Radiometric age determinations were undertaken on 15 kimberlite occurrences in Southern Africa, emphasis being placed on a wide areal distribution of occurrences, and on occurrences for which pre-Karroo ages are indicated by field relationships. The $\mathrm{Rb}-\mathrm{Sr}$ method, applied to mica (usually phlogopite), was used where possible. An alternative method, utilising the $\mathrm{U}-\mathrm{Pb}$ isochron approach on whole rock and perovskite-enriched samples, was tested with a view to its application on samples devoid of mica.

$\mathrm{Rb}-\mathrm{Sr}$ ages. New $\mathrm{Rb}-\mathrm{Sr}$ age measurements are listed below. Other data by the same method are given in Allsopp and Barrett (1975). Further measurements are still in progress, for which reason the new data may be subject to minor revision. A value of $1.39 \times 10^{-11} \mathrm{yr}^{-1}$ was used for the ${ }^{87} \mathrm{Rb}$ decay constant.

Letseng-1a-Terai, a pipe which cuts the uppermost Drakensberg basalts (age $180 \mathrm{~m} \cdot \mathrm{y} \cdot$, Fitch and Miller, 1971) in Lesotho yielded mica ages of 380 , 580 and $660 \mathrm{~m} \cdot \mathrm{y}$. The pipe contains abundant basement xenoliths and the data may reflect incorporation of basement mica. Microprobe examination of the mica in question is in progress.

Finsch, in the northern Cape Province, yielded two ages of 130 and 170 m.y.. These data are compatible with the post-Karroo field relationship of this pipe.

Njoio and Tchivira, two intrusions with kimberlitic affinities in central Angola, were dated using mica and K-feldspar, and the result obtained was $130+10 \mathrm{~m} \cdot \mathrm{y}$..

Swartruggens (Transval). The age of Swartruggens reported by A11sopp and Barrett (1975) was confirmed ( $150 \pm 3 \mathrm{m.y.})$; no difference in age between the two fissures at Swartruggens could be discerned.

Colossus, a pipe situated in central Rhodesia, yielded a mica isochron age of $490 \pm 20 \mathrm{~m} \cdot \mathrm{y}$.. The samples, available only from surface dumps, were all altered and the uncertainty in the result may have been underestimated.

National, a pipe situated close to the Premier pipe in the Transval, yielded a mica-isochron age of $1180 \pm 30 \mathrm{~m} . \mathrm{y} .$. The samples were again from weathered surface outcrops.

Premier data were previously reported by Barrett and Al1sopp (1973) but not published in full because further work was intended. Unfortunately deve1opment in the mine has not yet permitted collection of fresh samples of the oldest type (2) kimberlite at distances sufficiently remote from the crosscutting sill. Available $\mathrm{Rb}-\mathrm{Sr}$ evidence indicates an age of $1250 \mathrm{~m} \cdot \mathrm{y}$. for the type 1 and about $1200 \mathrm{~m} \cdot \mathrm{y}$. for the type 4 kimberlites.

Camafuca, from Angola, yielded a mica isochron age of $1810 \pm 20 \mathrm{~m} \cdot \mathrm{y} \cdot$, a result in gross conflict with the supposed post-Karroo age of this intrusion. This result is further discussed below.

Discussion of $\mathrm{Rb}-\mathrm{Sr}$ ages. In several cases the $\mathrm{Rb}-\mathrm{Sr}$ ages obtained are in conflict with established geological relationships. Two mechanisms that could account for such anomalous results are considered.

(i) The mica analysed could have been derived from an older source. This older source could be the basement intruded by the kimberlite, in which case the mica is more likely to be biotite than phlogopite. An example of this is Camafuca: Microprobe analysis shows the mica to be biotite, the distinction being based largely on the $\mathrm{Fe} / \mathrm{Mg}$ ratio. Allsopp and Barrett (1975) suggested that xenocrystic phlogopite could retain ages significantly, though not 
greatly, in excess of the kimberlite age. The effect would be most significant for the youngest pipes, and may account for some of the scatter between different $\mathrm{Rb}-\mathrm{Sr}$ ages from a particular pipe (e.g. Finsch), and for the differences between $\mathrm{U}-\mathrm{Pb}$ zircon ages (Davis, private communication) and $\mathrm{Rb}-\mathrm{Sr}$ ages from some occurrences (e.g. Finsch and Roberts Victor).

(ii) A linear or near-linear array of data points on an isochron diagram may also be the result of contamination by unradiogenic Sr. Micaceous wholerock kimberlites have initial ${ }^{8} \mathrm{Sr} /{ }^{86} \mathrm{Sr}$ ratios of around .708 (Barrett and Berg, 1975), but the leachable carbonate component usually has an ${ }^{87} \mathrm{Sr} /{ }^{86} \mathrm{Sr}$ ratio of around .704 (Brookins, 1967). Therefore two different initial ratios can exist within the same kimberlite, and contamination of the radiogenic Sr in the mica with the $\mathrm{Sr}$ from the carbonate component might give rise to apparent ages which are too high. This effect would only be significant if the present-day ${ }^{87} \mathrm{Sr} /{ }^{86} \mathrm{Sr}$ ratios of the micas are less than about .75, and for most of the data reported here the influence of this factor is negligible.

$\mathrm{U}-\mathrm{Pb}$ dating. Kleeman and Lovering (1973) have reported that uranium in the kimberlite matrix is very strongly concentrated into secondary perovskite and into alteration rims of ilmenite. Carbonate minerals of the kimberlite matrix are on the other hand extremely poor in uranium. The partitioning of uranium in this way presumably took place during, or shortly after, pipe formation. If closed-system behaviour prevailed since then, a mineral-isochron approach whereby $238 \mathrm{U} /{ }^{204} \mathrm{~Pb}$ is plotted against ${ }^{206} \mathrm{~Pb} /{ }^{204} \mathrm{~Pb}$, might yield the pipe age. The crudest approach to obtaining two "phases" of a matrix kimberlite suitable for such a plot is to leach the kimberlite in $\mathrm{HCl}$, dissolving mainly the garbonate. The pair leach-residue is plotted in a $206 \mathrm{~Pb} / 204 \mathrm{~Pb}$ vs. ${ }^{238} \mathrm{U} /{ }^{204} \mathrm{~Pb}$ isochron diagram. Age-values were obtained in this way for the pipes Wesselton, Dutoitspan and Monastery. They are shown in Table 1 and compared with results reported by Allsopp and Barrett (1975).

Table 1: $\mathrm{U}-\mathrm{Pb}$ and $\mathrm{Rb}-\mathrm{Sr}$ ages.

$\begin{array}{lll}\text { Sample } & \frac{\text { age } \mathrm{U}-\mathrm{Pb}}{20 \pm 4 \mathrm{~m} \cdot \mathrm{y} \cdot} \frac{\text { age } \mathrm{Rb}-\mathrm{Sr}}{83,84 \mathrm{~m} \cdot \mathrm{y} \cdot} \text { (Allsopp and Barrett, 1975) } \\ \text { Wesselton } & 97 \pm 6 \mathrm{~m} \cdot \mathrm{y} \cdot--- \text { (assumed same age as Wesselton) } \\ \text { Dutoitspan } & 83 \pm 5 \mathrm{~m} \cdot \mathrm{y} \cdot 90 \mathrm{~m} \cdot \mathrm{y} \cdot\end{array}$

The perovskite in the kimberlite matrix is fine-grained ( $\phi$ 5-50 micron). Separation of a perovskite-enriched fraction by heavy liquids and magnetic separation is easy, but handpicking is required to obtain a pure concentrate. Age determinations involving separation of a perovskite-enriched fraction were made on samples from the following pipes:

Table 2: $\mathrm{U}-\mathrm{Pb}$ and $\mathrm{Pb}-\mathrm{Pb}$ ages.

\begin{tabular}{|c|c|c|}
\hline Sample & age $206-238$ & age $207-206$ \\
\hline (Kimberley) & $92 \pm 4 \mathrm{~m} \cdot \mathrm{y}$. & $120+100 \mathrm{~m} \cdot \mathrm{y} \cdot$ \\
\hline Colossus (Rhodesia) & $660^{-} \pm 20 \mathrm{~m} \cdot \mathrm{y}$. & $330 \pm 60 \mathrm{~m} \cdot \mathrm{y}$ \\
\hline Beit Bridge (") & $420 \mp 20 \mathrm{~m} \cdot \mathrm{y}$. & $730 \pm 60 \mathrm{~m} \cdot \mathrm{y}$ \\
\hline Dokolwayo (Swazil and) & $300 \mp 20 \mathrm{~m} \cdot \mathrm{y}$ & $400 \mp 200 \mathrm{~m} \cdot \mathrm{y}$. \\
\hline $\begin{array}{l}\text { Goedgevonden } \\
\text { (Transvaa1) }\end{array}$ & $117 \pm 4 \mathrm{~m} \cdot \mathrm{y}$ & $150 \pm 100 \mathrm{~m} \cdot \mathrm{y}$. \\
\hline
\end{tabular}

Age determinations involving mineral separation were also attempted on five samples from the Premier mine, representing types 1,2 and 3 as mapped by mine geologists. A good spread in $\mathrm{U} / \mathrm{Pb}$ ratios and $\mathrm{Pb}$ isotopic compositions was only obtained for samples from type 3 . The $207 / 206$ age for this kimberlite 
Was $1250 \pm 50 \mathrm{~m} \cdot \mathrm{y}$. , whereas values of 800 and $940 \mathrm{~m} \cdot \mathrm{y}$. were obtained for the $206 \mathrm{~Pb}-238 \overline{\mathrm{U}}$ age. In the case of type 1 , the situation was complicated by sulphides which had apparently incorporated radiogenic lead at a time substantially after pipe formation.

Generally, it seems that ages obtained by the U-Pb mineral isochron method are roughly concordant for kimberlites round $100 \mathrm{~m} . \mathrm{y}$. old, but that lead loss (as in Premier, Type 3, and Beit Bridge) or uranium loss (as in Colossus) can occur in the more uranium-rich fraction analysed, if the samples are substantially older. However, the significance and relative precision of the lead $207 / 206$ age of a sample increases with the actual sample age. For older samples, the effect of uranium- or lead loss is best visualised by the use

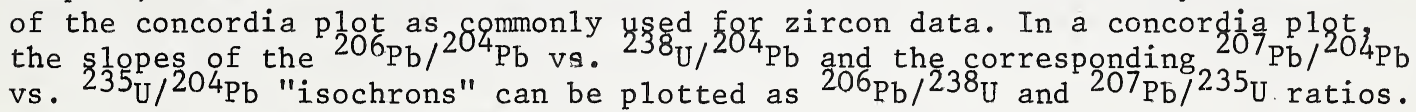
While it appears that the U-Pb mineral isochron method, applied to kimber1itic minerals, can provide answers that are roughly correct, we feel that this method should only be used as a "last measure" in cases where no alternative method can be applied.

The data reported above shows that Southern African kimberlites range widely in age. With the establishment of this range, it becomes clear that no particular correlation in time and place between kimberlite occurrence and large-scale volcanic activity (such as the Karroo volcanism) can be maintained.

\section{References}

H.L. Allsopp and D.R. Barrett (1975): Rb-Sr age determinations on South African kimberlite pipes. Physics and Chemistry of the Earth, 9 (Pergamon Press), pp 605-617

D.R. Barrett and H.L. Allsopp (1973): rubidium-strontium age determinations on South African Kimberlite pipes. First International Kimberlite Conference, extended abstract volume (University of Cape Town), pp 23-25.

D.R. Barrett and G.W. Berg (1975): Complementary petrographic and strontiumisotope ratio studies of South African kimberlite. Physics and Chemistry of the Earth, 9 (Pergamon Press), pp619-635

D.G. Brookins (1967): The strontium geochemistry of carbonates in kimberlites and limestones from Riley County, Kansas. Earth and Planetary Science Letters, 2, pp 235-240.

F.J. Fitch and J.A. Miller (1971): Potassium-argon radioages of Karroo volc anic rocks from Lesotho. Bulletin Volcanologique, XXXV, pp 64-84.

J.D. Kleeman and J.F. Lovering (1973): Uranium partitioning in kimberlites and their deep-seated inclusions. First International Kimberlite Conference, extended abstract volume (University of Cape Town), pp 189-190. 